\title{
The Effects of Student and School Level Characteristics on Academic Achievement of Middle School Students in Turkey*
}

\author{
Pinar KARAMAN ** $\quad$ Burcu ATAR ***
}

\begin{abstract}
The purpose of the study was to examine the student-level and school-level variability that affect middle school students' academic achievement. Student background and school context on student academic achievement were examined. Participants of the study consisted of 1053 seventh and eighth grade middle school students from 10 schools in the cities of Ankara and Sinop, Turkey. The research study analysed using two-level hierarchical linear modeling (HLM). Data were analysed with three HLM models: (1) random effects one-way ANOVA model, (2) random coefficients regression model, (3) intercepts and slopes-as outcomes model. The results of the analyses showed that at the student level, gender, SES, and number of siblings were found to have statistically significant effects on student GPA. When considering the practical importance of student level variables, SES, and number of siblings have small effects, but gender has a moderate effect on students' school achievements. On average, female students perform higher than male students in terms of their GPA scores. At the school level, educational school resources have a significant effect on predicting academic achievement. It has been shown that school resources have a moderate effect on students' academic achievements.
\end{abstract}

Key Words: Hierarchical linear modeling, academic achievement, student GPA, gender, SES, school resources.

\section{INTRODUCTION}

Academic achievement is one of the most important determinants of education quality. Educational researchers agree that many factors have an impact on students' achievements (Börkan \& Bakış, 2016; Coleman et al., 1966; Engin-Demir, 2009; Gelbal, 2008). To monitor the quality of education, educational assessment studies associated with academic achievement are taken into consideration in many countries. Therefore, studies related to the determinants of student achievement are dramatically increased over several decades. Student achievement depends on several factors, such as individual factors, family factors, school factors.

The research studies have shown that student characteristics such as gender, age, motivation, attitudes towards courses, self-efficacy, students' efforts, being bullied at school have significant impacts on academic achievement (Engin-Demir, 2009; Gevrek \& Sieberlich, 2014; Ma, 2001; Özberk, AtalayKabasakal \& Boztunç-Öztürk, 2017, Yavuz, Demirtaşl1, Yalçın, \& İlgün-Dibek, 2017). Family background characteristics such as family socioeconomic status (SES), family size or number of children in the family, and parental education are related to educational achievement (Alacacı \& Erbaş, 2010; Börkan \& Balkış, 2016; Downey, 2001; Engin-Demir, 2009; Kalender \& Berberoglu, 2009; Ministry of National Education-MoNE, 2007). The students whose families have a lower status, a lower level of education, and a bigger size are more likely to have lower academic performance in schools (Gamboa \& Waltenberg, 2012; Willms, 1996). On the other hand, some students with low SES are able to show much higher academic performance than their peers with high SES (Erberber et al., 2015; Organisation for Economic Co-operation and Development-OECD, 2011; Özberk et al., 2017). These students are

\footnotetext{
* This study was presented at the International Congress of Eurasian Educational Researches held in Ankara on June 19-22, 2019.

** Assist. Prof., Sinop University, Faculty of Education, Sinop-Turkey, pkaraman1626@ gmail.com, ORCID ID: 0000-00022218-2701

*** Assoc. Prof., Hacettepe University, Faculty of Education, Ankara-Turkey, burcugulum@gmail.com, ORCID ID: 00000003-3527-686X
}

To cite this article:

Karaman, P. \& Atar, B. (2019). The effects of student and school level characteristics on academic achievement of middle school students in Turkey. Journal of Measurement and Evaluation in Education and Psychology, 10(4), 391-405. doi: 10.21031/epod.564819 
called as academically resilient students. Research studies have shown that family characteristics are strong effects on student achievement whereas school characteristics have weak effects (Baker, Goesling, \& Letendre, 2002; Brooks-Gunn and Duncan, 1997; Coleman et al., 1966; Heyneman \& Loxley, 1983). However, there has been considerable debate on whether school characteristics have a significant effect on student outcomes (Chevalier \& Lanot, 2002; Hanushek, 1997). Several research implied that in some contexts, school resources and teacher characteristics have a significant impact on student achievement (Atar, 2014; Bilican-Demir, 2018; Darling-Hammond, 2000; Glewwe, Kremer, Moulin \& Zitzewitz, 2004; Leon \& Valdivia, 2015; Phan, 2008; Sweetland \& Hoy, 2000; Tavşanc1l \& Yalçın, 2015; Yavuz et al., 2017). School characteristics, especially in developing countries, determine the school quality. To examine school effects, different strategies can be used in the studies such as student-teacher ratio, school size, class size, instructional materials, teacher quality, school resources (libraries, labs, computers, etc.) (Leon \& Valdivia, 2015; Willms \& Somers, 2001). The results indicated that schools with better physical facilities (e.g., libraries, labs, textbooks) and qualified teachers, especially for developing countries, contribute positively to increase student achievement (Alacac1 \& Erbaş, 2010; Baker et al., 2002).

\section{Assessment of Student Achievement}

Several methods can be used to assess student achievement. Final grades or grade point average (GPA) are generally used for students' achievements at school. On the other hand, standardized achievement tests are also used to assess student achievement (Petrill \& Wilkerson, 2000). International educational large-scale assessments such as The Trends in International Mathematics and Science Study (TIMSS), Programme for International Student Assessment (PISA), and Progress in International Reading Literacy Study (PIRLS) and national large-scale assessments are generally used to evaluate student achievement. Numerous studies have been conducted in Turkey to examine student achievement on TIMSS, PISA, or PIRLS data (Akyüz, 2014; Alacac1 \& Erbaş, 2010; Anıl, 2009; Atar, 2014; Atar \& Atar, 2012; Dincer \& Uysal, 2010; Özberk et al., 2017; Özdemir, 2016; Yalçın, Demirtaşlı, İlgün-Dibek, \& Yavuz, 2017). However, a few studies conducted in Turkey to examine student academic achievement on national large scale assessment such as Placement Test Results (SBS), Student Achievement Determination Exam (ÖBBS), Transition from Primary to Secondary education (TEOG) or on students' GPA in schools (Börkan \& Bakış, 2016; Çiftçi, 2015; Engin-Demir, 2009; Gelbal, 2008; Yavuz, Tan \& Atar, 2019).

The literature showed that academic achievement and its relationship with student characteristics and school characteristics is one of the enduring issues. Student characteristics such as gender, SES, number of siblings were examined in the study since these variables are mostly used contextual variables and likely to influence educational achievement. To determine whether school characteristics make a difference in student achievement, three categories (school size, student-teacher ratio, school resources) were measured. Therefore, the aim of the study was to provide empirical evidence on the relationship between student and school characteristics and student GPA in Turkey. Multilevel modeling was used to assess these factors on student achievement. Four research questions were investigated in the study:

1. How much do schools differ in their mean academic achievements?

2. How much do schools differ regarding the association between student level variables (i.e., gender, SES, number of siblings) and academic achievement?

3. Are school level variables (school size, student-teacher ratio, school resources) significant predictors of mean academic achievement?

4. Are school level variables (school size, student-teacher ratio, school resources) significant predictors of within school associations? 


\section{METHOD}

\section{Sample and Data}

The study group included 1053 Grade 7 and Grade 8 students from 10 public middle schools in the cities of Ankara and Sinop, Turkey. A typical case sampling method was used to represent the average of middle school students in the province of Ankara and Sinop (Büyüköztürk, Çakmak, Akgün, Karadeniz \& Demirel, 2008). The participants consisted of 512 females (48.6\%) and 541 males (51.4\%). The average age was 13.46 years, and age range was between 12-15.

\section{Data Collection Instrument}

1053 middle school students in 10 schools have completed survey questions which including only demographic questions. Several demographic questions (gender, SES, number of siblings) were asked to the students in the survey. While some of the variables were categorical, some others were continuous. Variables that are thought to affect student achievement were determined. Gender, SES, and the number of siblings were assigned as student level variables. School size, student-teacher ratio, and educational resources were assigned as school level variables. School level variables were obtained from the Ministry of National Education (MEB) e-school system. Students' GPA as composite achievement scores were obtained from school administrative records. In schools, teacher-based exams are applied to students and GPA affects students' high school placement results.

Students' GPA scores were included as a continuous dependent variable in the HLM analyses. Since gender is a dummy variable, female students were coded as 1 , and male students were coded as 2 . SES was measured with parental income. Students were asked to provide information about their family's SES in the survey. SES was ranged from lower to upper as low SES, lower-middle SES, middle SES, upper-middle SES, and high SES. This variable was coded as low $=1$, lower-middle $=2$, middle $=3$, upper-middle $=4$, and high $=5$. Educational resources (e.g. music room, art room, computer lab, science lab, library, conference room, atelier, sports room) in schools were examined. Scoring school resources was ranged from the highest score (8) to the lowest score (1). Schools' scores between 7-8 score, 5-6 score, 3-4 score, and 1-2 score were categorized as a lot (4), some (3), little (2), and very little (1), respectively. Therefore, SES and educational resources have been considered as ordinal variables. The number of siblings, school size, and student-teacher ratio were continuous variables in the study. School size was measured by the number of students per school. The student level and school level variables have shown in Table 1. The mean values of categorical variables such as gender, SES, and educational resources represent the proportion of frequency of these variables in Table 1.

Table 1. Descriptive Statistics for Variables

\begin{tabular}{|c|c|c|c|}
\hline Variables & $\mathbf{N}$ & Mean & Sd \\
\hline \multicolumn{4}{|l|}{ Student level } \\
\hline Gender & 1053 & 1.51 & 0.50 \\
\hline SES & 1053 & 3.36 & 0.76 \\
\hline Number of Siblings & 1053 & 2.34 & 0.96 \\
\hline \multicolumn{4}{|l|}{ School level } \\
\hline School Size & 10 & 492.30 & 181.37 \\
\hline Student-teacher ratio & 10 & 13.40 & 1.77 \\
\hline Educational resources & 10 & 2.70 & 0.82 \\
\hline Outcome variable (GPA) & 1053 & 83.94 & 12.10 \\
\hline
\end{tabular}

\section{Design of the Study}

This study aimed to examine the effects of variables at the student level and school level on middle school students' academic achievement in Turkish public schools. Due to the nested nature of data, the 
Hierarchical Linear Modeling methodology was used in the present study. Conducting HLM analysis for nested structure of data helps to prevent making a Type I error and biased results (Gill, 2003; Osborne, 2000; Raudenbush \& Bryk, 2002). HLM helps to determine the direct effects of variables at individual level and student level (Hox, 1995). For HLM analysis, adequate sample sizes must be obtained. There are several suggestions about the number of groups required for multilevel model (MLM) studies. The minimum cluster size of 20 (Tabachnick \& Fidell, 2014), cluster size of 30 (Kreft, 1996), or even cluster size of 50 (Hox, 1998, 2010) is recommended in MLM studies. Moreover, the simulation studies advise that multilevel model should not be used if the number of clusters less than 10 (McNeish \& Stapleton, 2016; Snijders \& Bosker, 1993). When using small sample size for MLM studies, restricted maximum likelihood or Kenward-Roger adjustment is recommended to reduce biased estimates (Boedeker, 2017; McNeish \& Stapleton, 2016). In this study, maximum and minimum number of students in schools was 235 and 68, respectively. Two-level models are analyzed using restricted maximum likelihood estimation by default in HLM 7 software (Raudenbush, Bryk, Cheong, Congdon \& du Toit, 2011).

\section{Data Analysis}

For HLM analysis, the two-level model was applied that student level was at the first level, and school level was at the second level. Student variables as the lowest level of the hierarchy are nested within schools (level 2). Analyzing the level 1 (student level) and level 2 (school level) regression relationship helps to determine the relationship between the predictors and outcome variables (Woltman, Feldstain, MacKay \& Rocchi, 2012). Each level in the hierarchical structure has its own sub-model that explains the relationships among the variables. The student level factors in the HLM analyses included gender, SES, and family size (number of siblings). School level factors were school size, student-teacher ratio, and educational recourses. Before the analysis, the assumptions of HLM were checked. The normality of error terms (level 1 residuals and level 2 residuals) was assessed (Raudenbush et al., 2011). QQ plots showed that the residuals are normally distributed.

The HLM modelling consisted of three steps. In the first step, null (unconditional) model with random effects ANOVA model was created with only student level outcome variable but not included predictors at student level and school level. It gives the proportion of variance in middle school students' academic achievement among schools. The variance of students' GPA scores was analyzed at the individual level and also at school level. Student level variables were centered around their group means, and school level variables were centered around their grand means in the HLM analysis. Centering can help the interpretation of the model intercepts easily by transforming these scores (Enders \& Tofighi, 2007; Raudenbush \& Bryk, 2002).

\section{Random effects one-way anova model}

Equations for random effects Anova model regarding this study are as follows:

Level 1 Model (Student Level): $Y_{i j}=\beta_{0 j}+r_{i j}$

Level 2 Model (School Level): $\beta_{0 j}=\gamma_{00}+u_{0 j}$

In student level model, $Y_{i j}$ refers to GPA of student $i$ in school $j . \beta_{0 j}$ refers to the mean of student GPA in school $j$, and $r_{i j}$ refers to deviation of student GPA in school $j$ from mean student GPA of school $j$. $\gamma_{00}$ is the grand mean of student GPA of $j$ schools, and $u_{0 j}$ is the deviation of the mean of student GPA of school $j$ from grand mean of student GPA.

\section{Random coefficient regression model}

In the model, the independent variables (gender, SES, number of siblings) were examined to determine whether they have a significant effect on students' GPA, on average. Equations for random coefficient regression model are as follows: 
Level 1 model:

$Y_{i j}=\beta_{0 j}+\beta_{1 j}\left(\right.$ gender $\left._{i j}\right)+\beta_{2 j}\left(\right.$ SES $\left._{i j}\right)+\beta_{3 j}\left(\right.$ number of sibling $\left._{i j}\right)+r_{i j}$

Level 2 model:

$\beta_{0 j}=\gamma_{00}+u_{0 j}$

$\beta_{1 j}=\gamma_{10}+u_{1 j}$

$\beta_{2 j}=\gamma_{20}+u_{2 j}$

$\beta_{3 j}=\gamma_{30}+u_{3 j}$

Intercepts and slopes-as outcomes model

Intercept and slope coefficients are outcomes in the model. This model also called as full model since both student level and school level variables were included. Equations for intercepts and slopes-as outcomes model regarding this study are as follows:

Level 1 model:

$Y_{i j}=\beta_{0 j}+\beta_{1 j}\left(\right.$ gender $\left._{i j}\right)+\beta_{2 j}\left(\right.$ SES $\left._{i j}\right)+\beta_{3 j}\left(\right.$ number of sibling $\left.g_{i j}\right)+r_{i j}$

Level 2 model:

$\beta_{0 j}=\gamma_{00}+\gamma_{01}($ schoolsize $)+\gamma_{02}($ student - teacher ratio $)+\gamma_{03}($ school recources $)+u_{0 j}$

$\beta_{1 j}=\gamma_{10}+u_{1 j}$

$\beta_{2 j}=\gamma_{20}+u_{2 j}$

$\beta_{3 j}=\gamma_{30}+u_{3 j}$

\section{RESULTS}

Results of The First Research Question (How much do schools differ in their mean academic achievements?):

The random-effects Anova model determines whether there is enough school variance to justify the use of multilevel analysis for data set. None of the predictors at level 1 and level 2 here are included in the null (unconditional) model. The result of the one way ANOVA with random effects were presented in Table 2.

Table 2. Estimation of Fixed Effect on Anova Model

\begin{tabular}{lllll}
\hline Fixed Effect & Coefficient & Standard Error & t ratio & df \\
\hline Average GPA, $\gamma_{00}$ & 83.07 & 1.52 & $57.59^{* *}$ & 9 \\
\hline$* * p<.001$ & & & &
\end{tabular}

Table 3. Estimation of Random Effects Anova Model

\begin{tabular}{lccl}
\hline Random effect & Variance & $\chi \mathbf{2}$ & df \\
\hline School level, $u_{0 j}$ & 21.54 & $116.07 * *$ & 9 \\
Level 1 effect, $r_{i j}$ & 133.67 & & \\
\hline$* * p<.001$ & & & \\
\hline
\end{tabular}


According to Table 2, overall school mean was 83.07 with 1.52 standard error. And in Table 3, the within-school variance was estimated as 133.67. The between-school variance was estimated as 21.54. The results showed that school level variance was statistically significant $\left(\chi_{(9)}^{2}=116.07, p<.001\right)$. Indicating that mean student GPA was significantly varied among schools. The null model also provides the estimate of the intraclass correlation coefficient. The intraclass correlation coefficient (ICC) was calculated to indicate the proportion of variance in student GPA among schools. The intraclass correlation was calculated as $\rho \rho=\tau_{00} /\left(\tau_{00}+\sigma^{2}\right)=21.54 /(21.54+133.66)=.14$ which indicated that $14 \%$ of total variance in student GPA was accounted for by differences among schools. $86 \%$ of the variability in student GPA resulted from the within-school variance. It has been found that estimated ICC value was larger than threshold of 5\% (Bliese, 2000). The result suggested that HLM analysis is necessary for the nested data.

Results of the Second Research Question (How much do schools differ regarding the association between student level variables (i.e., gender, SES, number of siblings) and academic achievement?):

Table 4 and Table 5 showed that the results obtained from the random coefficient model analysis.

Table 4. Estimation of Fixed Effects on Random Coefficient Model

\begin{tabular}{llllll}
\hline Fixed effect & Coefficient & Standard Error & t-ratio & df & Effect size \\
\hline Average GPA, $\gamma_{00}$ & 83.07 & 1.43 & $57.84^{* *}$ & 9 & \\
Gender, $\gamma_{10}$ & -4.82 & 1.17 & $-4.09^{*}$ & 9 & .43 \\
SES, $\gamma_{20}$ & 1.08 & 0.44 & $2.42^{*}$ & 9 & .10 \\
Number of Sibling, $\gamma_{30}$ & -1.28 & 0.47 & $-2.74^{*}$ & 9 & .11 \\
\hline
\end{tabular}

**p $<.001 ; * p<.05$

Table 5. Estimation of Variance Components on The Random Coefficient Model

\begin{tabular}{lllll}
\hline Random effect & Variance & Standard Deviation & $\chi^{\mathbf{2}}$ & df \\
\hline School level, $u_{0 j}$ & 21.46 & 4.63 & $121.48^{* *}$ & 9 \\
Level 1 effect, $r_{i j}$ & 124.94 & 11.17 & & \\
\hline$* * p<.001$ & & &
\end{tabular}

The findings indicated that the mean effects of the gender, SES, and number of siblings on student GPA were statistically significant. The independent variables had a significant effect on students' GPA scores at the student level. The mean slope values associated with the independent variables were estimated as $-4.82,1.08,-1.28$, respectively. Negative coefficient value for gender suggests that on average, female students' GPA scores were about five points higher than male students when holding other variables constant $\left(\gamma_{10}=-4.82\right)$. And also on average, one unit increase in number of siblings, student GPA score decreased one point when controlling all other variables $\left(\gamma_{30}=-1.28\right)$. It indicated that number of siblings was negatively correlated with student GPA score. On the other hand, SES positively contributed to students' GPA scores $\left(\gamma_{20}=1.08\right)$. The effect size of each variable was also estimated to interpret the practical significance of variables (Kelley \& Preacher, 2012). The effect size of each variable was estimated as $.43, .10$, and .11, respectively. Female students' GPA on average is 0.43 standard deviation higher than that of male students. It means that gender variable has moderate effect on student GPA. On the other hand, SES and number of siblings variables on academic achievement have a small effect (Cohen, 1992).

After student level variables were added to the model, within-school variance was reduced from 133.67 to 124.94. The results suggested that these variables in students' GPA scores explain only $7 \%$ of withinschool variability $\left(\mathrm{r}^{2}=.07\right)$. 
Karaman, P., Atar, B. / The Effects of Student and School Level Characteristics on Academic Achievement of Middle School Students in Turkey

Results of the Third Research Question (Are school level variables (school size, student-teacher ratio, school resources) significant predictors of mean academic achievement?)

The results of the intercepts and slopes as outcomes model for fixed effects were presented in Table 6.

Table 6. Results of The Fixed Effect in the Full Model

\begin{tabular}{llllll}
\hline Fixed effect & Coefficient & Standard Error & t-ratio & df & Effect Size \\
\hline Intercept (GPA), $Y_{00}$ & 83.03 & 1.24 & $66.65^{* *}$ & 9 & \\
Student level & & & & & -.40 \\
Gender, $\gamma_{10}$ & -4.66 & 1.04 & $-4.44^{*}$ & 9 & .09 \\
SES, $Y_{20}$ & 1.07 & 0.44 & $2.39^{*}$ & 9 & -.10 \\
Number of Sibling, $Y_{30}$ & -1.25 & 0.48 & $-2.60^{*}$ & 9 & \\
School level & & & & & \\
School size, $Y_{01}$ & 0.003 & 0.005 & -2.19 & 6 & .27 \\
Student-teacher ratio, $Y_{02}$ & -0.79 & 0.36 & $3.09^{*}$ & 6 & \\
School resources, $Y_{03}$ & 3.11 & 1.00 & & \\
\hline
\end{tabular}

** $p<.001 ; * p<.05$

At the student level, gender, SES, and the number of siblings were found to have a significant impact on student GPA. The coefficient values of independent variables were estimated to be $-4.66,1.07$, and -1.25 , respectively. Negative coefficient value for gender suggests that on average, female students' GPA scores were about five points higher than male students when holding other variables constant $\left(\gamma_{10}=-4.66\right)$. And also on average, one unit increase in number of siblings, student GPA score decreased one point when controlling all other variables $\left(\gamma_{30}=-1.25\right)$. It indicated that number of siblings was negatively correlated with student GPA score. On the other hand, SES positively contributed to students' GPA scores. At the school level, only school resources found to have statistically significant effect on mean academic achievement $(\mathrm{p}=0.021)$. It suggested that school educational resources were positively related to students' academic performance. And also the effect sizes of the variables at student level and school level were estimated. Effect sizes for student variables were found $-0.40,0.09$, and -0.10 , respectively. While gender variable had medium effect on student GPA, SES and number of siblings variables had small effect on student GPA. At the school level, effect size of school resources indicated that an increase of one standard deviation in school resources would result in an increase of 0.27 standard deviation in the school mean student GPA. It showed that school resources had approximately medium effect on academic achievement.

Results of the Fourth Research Question (Are school level variables (school size, student-teacher ratio, school resources) significant predictors of within school associations?)

The results of the intercepts and slopes as outcomes model for random effects were presented in Table 7.

Table 7. Estimation of Variance Components on the Full Model

\begin{tabular}{lllll}
\hline Random effect & Variance & Standard Deviation & $\chi^{2}$ & df \\
\hline School level, $u_{0 j}$ & 19.23 & 4.38 & $122.92^{* *}$ & 6 \\
Level 1 effect, $r_{i j}$ & 124.96 & 11.17 & & 9 \\
\hline$* * p<.001$ & & & &
\end{tabular}

According to Table 7, adding student level and school level variables to the null model decreased school variability from 21.54 to 19.23 . This finding indicated that school level variables explained $11 \%$ of the between-school variability in students' GPA scores. And also student variance in the full model 
decreased between from 133.67 to 124.96 . It showed that student level variables explained $7 \%$ of the within-school variability in students' GPA scores. In comparison with the null model, final model explained approximately $7 \%$ of the variance at the student level, and $11 \%$ of the variance at the school level and remaining variability is still statistically significant $(p<.001)$.

\section{DISCUSSION and CONCLUSION}

This study empirically investigated the effects of student characteristics and school characteristics on the academic achievement of middle school students in Turkey. The findings indicated that student characteristics including gender, SES, and the number of siblings have significant effects on academic achievement. Student variables explained 7\% variance in academic achievement. Gender has strongly significant effect on student academic achievement. Female students had higher average GPA scores than male students after controlling other variables. This finding is consistent with several studies (Börkan \& Bakış, 2016; Dayioğlu \& Türüt-Aş1k, 2007; Engin-Demir, 2009; Ferreira \& Gignoux, 2010; Gevrek \& Seiberlich, 2014; Güvendir, 2014; Van Houtte, 2004). For example, Engin-Demir (2009) studied with sixth, seventh, and eighth grade students to investigate factors influencing their academic success by using their GPA. This study found that gender is the most important factor among student characteristics. On average, female students had higher achievement scores than male students in that study. Dayioğlu and Türüt-Asık (2007) examined the gender gap in academic performance for undergraduate students. They found that female students outperform male students in cumulative GPA, but the gender gap in university entrance exam scores was in reverse. Several reasons may explain why female students outperform male students in schools. Their attitudes and self-efficacy toward school, sense of school belongings, academic motivation, their efforts toward courses influence female and male students' academic achievement differently (Batyra, 2017; Engin-Demir, 2009; Gevrek \& Seiberlich, 2014; Johnson, Crosnoe \& Elder 2001; OECD, 2016; Van Houtte, 2004; Veenstra \& Kuyper, 2004). Besides, gender equity for school achievement is very important. Turkey has made great efforts to advance gender equity since 2000. Since school enrollment, especially for females, has increased in primary and secondary education, gender differences in academic achievement are disappearing progressively in Turkey. The result of the present study may also show the positive effects of projects related to gender equity in schools throughout Turkey (The United Nations Children's FundUNICEF,2016). On the other hand, female students tend to show lower performance than male students in some subjects, especially in science and maths (Atar \& Atar, 2012; Berberoğlu, 2004; Chiu \& Xihua, 2008; Farkas, Sheehan, \& Grobe, 1990; Wößmann, 2003). Literature generally showed that gender differences exist in academic performance of students all around the world. Therefore, more research is needed to examine gender gap in academic achievement for gender equity in education.

Although effect sizes are small, the effects of the number of siblings and SES on academic achievement were significant. It was found that low SES students are more likely to get a lower GPA. Similarly, vast majority of research revealed that the students living in a low socio-economic status family show poorly performance in schools (Alacacı \& Erbaş, 2010; Atar \& Atar, 2012; Aypay, Erdogan, \& Sozer, 2007; Bellibas, 2016; Dincer \& Uysal, 2010; Flores, 2007; Gelbal, 2008; Kalaycioğlu, 2015; Ma \& Klinger, 2000; Perry \& McConney, 2010; Sirin, 2005; Smits \& Hosgör, 2006). Sirin (2005) used meta-analysis to examine the family effects on academic achievement. The results showed that socioeconomic structure has a medium to strong impact on academic achievement. The author suggested that to prevent overestimating the effects of SES using multiple components of SES (e.g. income, education, and occupation) is important. The present study also showed the negative siblings effects on academic achievement. Especially in developing countries and western countries, a negative relationship exists between large number of siblings and educational outcomes (Buchmann \& Hannum, 2001; Downey, 2001; Gelbal, 2008).

The impacts of school variables on academic achievement were examined. The findings revealed that approximately $11 \%$ of the variation in student GPA was explained by differences among schools. School quality was measured with school size, teacher-student ratio, and school resources. The effect of educational resources of schools (e.g., library, computer labs, science labs, music room) on academic achievement was moderate. School size and teacher-student ratio had no statistically significant effect 
on student achievement. The research findings showed that the effect of school resources on academic achievement was significant. However, there is no consensus about the effect of school resources on academic achievement. While most of the research found that school characteristics do not have significant effect on educational achievement research in developed and developing countries (Coleman et al.,1966; Hanushek, 1997; Hanushek \& Luque, 2003), some research emphasized that school resources are associated with student outcomes especially in developed countries (Card \& Krueger, 1996; Fuller \& Clarke, 1994; Glewwe et al.,2004; Leon \& Valdivia, 2015; Özberk et al., 2017). Leon and Valdivia (2015) concluded that when the distribution of schools was unequal, the influence of school characteristics on academic achievement was significant in developing countries. The authors suggested that improving school quality especially in poorer areas can help to close gender gap and socioeconomic gap in student achievement. The school with better physical environment is positively related to student outcomes (Adeogun \& Osifila, 2008; Krueger, 2003; Parcel \& Dufur, 2001). The present study showed that increases in educational resources in schools have a significant impact on student academic achievement. Therefore, this study suggests that investigating the determinants of student achievement is crucial to increase quality of education. More progress should be made to decrease the achievement gap in schools with educational policy movements in Turkey.

The study has also some limitations. Not many variables at student level and school level that effect student GPA were examined in this study. Student characteristics were measured with middle school students' background (demographic variables). However, it is also useful to examine the effect of other student variables on academic achievement (e.g. personality, intelligence). To determine the quality of schools, numerous resources can be considered such as teacher quality, institutional quality, physical resources, etc. School characteristics were measured into three categories in the present study. More variables should also be considered to measure school quality in further studies. School SES, geographical distribution of schools, school types, which may also potentially impact educational attainment, can also be considered in further studies. More research is needed to investigate the determinants of student achievement. Another limitation of this study was using self-reported data except students' GPAs. And also in the study, acceptable low limit to sample size at group level was used. Since getting larger groups is difficult for several reasons, the number of groups is usually a methodological concern in multilevel studies (Maas \& Hox, 2005). Therefore, further studies should be conducted to larger number of schools.

\section{REFERENCES}

Adeogun, A. A., \& Osifila, G. I. (2008). Relationship between educational resources and students' academic performance in Lagos State Nigeria. International Journal of Educational Management, 5(6), 144-153. Retrieved from http://www.unilorin.edu.ng/ejournals/ijern

Akyüz, G. (2014). TIMSS 2011'de öğrenci ve okul faktörlerinin matematik başarısına etkisi. Eğitim ve Bilim, 39(172), 150-162. Retrieved from: http://egitimvebilim.ted.org.tr/index.php/EB/article/view/2867

Alacac1, C., \& Erbaş, A. K. (2010). Unpacking the inequality among Turkish schools: Findings from PISA 2009. International Journal of Educational Development, 30(2), 182-192. doi: 10.1016/j.ijedudev.2009.03.006.

Anıl, D. (2009). Uluslararası öğrenci başarılarını değerlendirme programı (PISA)'nda Türkiye'deki öğrencilerin fen bilimleri başarılarını etkileyen faktörler. Eğitim ve Bilim, Eğitim ve Bilim, 34(152 ), 87-100. Retrieved from http://egitimvebilim.ted.org.tr/index.php/EB/article/view/594/74

Atar, H. Y. (2014). Öğretmen niteliklerinin TIMSS 2011 fen başarısına çok düzeyli etkileri. Eğitim ve Bilim, 39(172), 121-137. Retrieved from http://egitimvebilim.ted.org.tr/index.php/EB/article/view/2894

Atar, H. Y., \& Atar, B. (2012). Examining the effects of Turkish Education reform on students' TIMSS 2007 science achievements. Educational Sciences: Theory and Practice, 12(4), 2632-2636. Retrieved from https://files.eric.ed.gov/fulltext/EJ1002867.pdf

Aypay, A., Erdogan, M., \& Sozer, M. A. (2007). Variation among schools on classroom practices in science based on TIMSS-1999 in Turkey. Journal of Research in Science Teaching 44(10), 1417-1435. doi: $10.1002 /$ tea.20202

Baker, D. P., Goesling, B., \& Letendre, G. K. (2002). Socioeconomic status, school quality, and national economic development: A cross-national analysis of the "Heyneman Loxley Effect" on Mathematics and Science achievement. Comparative Education Review, 46(3), 291-312. doi: 10.1086/341159 
Batyra, A. (2017). Gender gaps in student achievement in Turkey: Evidence from the programme for international student assessment (PISA) 2015. Istanbul: Education Reform Initiative.

Bellibaş, M. Ş. (2016). Who are the most disadvantaged? Factors associated with the achievement of students with low socio-economic backgrounds. Educational Sciences: Theory \&Practice, 16(2), 691-710. doi: 10.12738/estp.2016.2.0257

Berberoğlu, G., (2004). Student learning achievement. Paper Commissioned for the Turkey ESS. World Bank, Washington, DC.

Bilican-Demir, S. (2018). The effect of teaching quality and teaching practices on PISA2012 mathematics achievement of Turkish students. International Journal of Assessment Tools in Education, 5(4), 645-658. Retrieved from https://doi.org/10.21449/ijate.463409

Bliese, P. D. (2000). Within-group agreement, non-independence, and reliability: Implications for data aggregation and analysis. In K. J. Klein \& S. W. J. Kozlowski (Eds.), Multi-level theory, research and methods in organizations: Foundations, extensions, and new directions (pp. 349-381). San Francisco, CA: JosseyBass.

Boedeker, P. (2017). Hierarchical linear modeling with maximum likelihood, restricted maximum likelihood, and fully bayesian estimation. Practical Assessment, Research \& Evaluation, 22(2), 1-19.

Börkan, B., \& Bakış, O. (2016). Determinants of academic achievement of middle schoolers in Turkey. Educational Sciences: Theory \& Practice, 16(6), 2193-2217. doi: 10.12738/estp.2016.6.0227

Brooks-Gunn, J., \& Duncan, G.J., (1997). The effects of poverty on children. The Future of Children, 7(2), 55-71. doi: $10.2307 / 1602387$

Buchmann, C., \& Hannum, E. (2001). Education and stratification in developing countries: A review of theories and research. Annual review of Sociology, 27, 77-103. doi: 10.1146/annurev.soc.27.1.77

Büyüköztürk, Ş., Çakmak, E. K., Akgün, Ö. E., Karadeniz, Ş., \& Demirel, F. (2008). Bilimsel araştırma yöntemleri (4. Baskı). Ankara: Pegem A Yayıncılık.

Card, D., \& Krueger, A. (1996). School resources and student outcomes: an overview of the literature and new evidence from North and South Carolina. Journal of Economic Perspectives 10(4), 31-40. doi: $10.3386 /$ w5 5708

Chevalier, A., \& Lanot, G., (2002). The relative effect of family characteristics and financial situation on educational achievement. Education Economics 10(2), 165-181. doi: 10.1080/09645290210126904

Chiu, M. M., \& Xihua, Z. (2008). Family and motivation effects on mathematics achievement: Analyses of students in 41 countries. Learning and Instruction, 18(4), 321-336. doi: 10.1016/j.learninstruc.2007.06.003

Cohen, J. (1992). A power primer. Psychological Bulletin, 112(1), 155-159. doi: 10.1037/0033-2909.112.1.155

Coleman, J.S., Campbell, E.Q., Hobson, C.J., McPartlant, J., Mood, A.M., Weinfall, F.D., \& York, R.L. (1966). Equality of Educational Opportunity. Department of Health, Education and Welfare, Washington, DC. doi:10.3886/ICPSR06389.v3

Çiftçi, Ş. K. (2015). Effects of secondary school student' perceptions of mathematics education quality on mathematics anxiety and achievement. Educational Sciences: Theory \& Practice, 15(6), 1487-1502. doi: 10.12738/estp.2015.6.2829

Darling-Hammond, L. (2000). Teacher quality and student achievement: A review of the state policy evidence. Education Policy Analysis Archives 8(1), 1-30. doi: 10.14507/epaa.v8n1.2000

Dayioğlu, M., \& Türüt-Aşik, S. (2007). Gender differences in academic performance in a large public university in Turkey. Higher Education, 53(2), 255-77. doi: 10.2307/29735052

Dincer, M. A., \& Uysal, G. (2010). The determinants of student achievement in Turkey. International Journal of Educational Development, 30(6), 592-598. doi: 10.1016/j.ijedudev.2010.05.005

Downey, D. B. (2001). Number of siblings and intellectual development. The resource dilution explanation. American Psychologist, 56(6), 497-504. Retrieved from http://dx.doi.org/10.1037/0003-066X.56.6-7.497

Enders, C. K. \& Tofighi, D. D. (2007). Centering predictor variables in cross-sectional multilevel models: A new look at an old issue, Psychol. Methods, 12(2), 121-138. doi: 10.1037/1082-989X.12.2.121

Engin-Demir, C. (2009). Factors influencing the academic achievement of the Turkish urban poor. International Journal of Educational Development, 29, 17-29. doi: 10.1016/j.ijedudev.2008.03.003

Erberber, E., Stephens, M., Mamedova, S., Ferguson, S., \& Kroeger, T. (2015). Socioeconomically disadvantaged students who are academically successful: Examining academic resilience crossnationally. IEA's Policy Brief Series, No. 5, Amsterdam, IEA.

Farkas, G., Sheehan, D., \& Grobe, R.P. (1990). Coursework mastery and school success: gender, ethnicity, and poverty groups within an urban school district. American Educational Research Journal 27(4), 807-827. Retrieved from https://doi.org/10.3102/00028312027004807

Ferreira, F. H., \& Gignoux, J., (2010). Inequality of opportunity for education: Turkey. In: R. Kanbur \& S. Michael (Eds.), Equity and growth in a globalizing world. Commission on growth and development (pp. 131-156). Washington DC: The World Bank. 
Flores, A. (2007). Examining disparities in mathematics education: Achievement gap or opportunity gap? The High School Journal, 91(1), 29-42. doi: 10.1353/hsj.2007.0022

Fuller, B., \& Clarke, P. (1994). Raising school effects while ignoring culture? Local conditions and the influence of classroom tools, rules and pedagogy. Review of Educational Research 64(1), 122-131. Retrieved from https://doi.org/10.3102/00346543064001119

Gamboa, L. F., \& Waltenberg, F. D. (2012). Inequality of opportunity in educational achievement in Latin America: Evidence from PISA 2006-2009. Economics of Education Review, 31(5), 694-708. doi: 10.1016/j.econedurev.2012.05.002

Gelbal, S. (2008). Sekizinci sınıf öğrencilerinin sosyoekonomik özelliklerinin türkçe başarısı üzerinde etkisi. Egitim ve Bilim, 33(150), 1-13. Retrieved from http://egitimvebilim.ted.org.tr/index.php/EB/article/view/626/96

Gevrek, Z. E., \& Seiberlich, R. R. (2014). Semiparametric decomposition of the gender achievement gap: An application for Turkey. Labour Economics, 31, 27-44. Retrievd from https://doi.org/10.1016/j.labeco.2014.08.002

Gill, J. (2003). Hierarchical linear models. In K. Kempf-Leonard (Ed.), Encyclopedia of social measurement. New York, NY: Academic.

Glewwe, P., Kremer, M., Moulin, S., \& Zitzewitz, E. (2004). Retrospective vs. prospective analyses of school inputs: The case of flip charts in Kenya. J. Dev. Econ., 74(1), 251-268. doi: 10.1016/j.jdeveco.2003.12.010

Güvendir, M. A. (2014). Öğrenci başarılarının belirlenmesi sınavında öğrenci ve okul özelliklerinin Türkçe başarısı ile ilişkisi. Eğitim ve Bilim, 39(172), 163-180.

Hanushek, E.A. (1997). Assessing the effects of school resources on student performance: an update. Educational Evaluation and Policy Analysis, 19(2), 141-164. doi: 10.3102/01623737019002141

Hanushek, E. A., \& Luque, J. A. (2003). Efficiency and equity in schools around the world. Economics of Education Review, 22(5), 481-502. Retrieved from https://ideas.repec.org/a/eee/ecoedu/v22y2003i5p481502.html

Heyneman, S. P., \& Loxley, W. A. (1983). The effect of primary school quality on academic achievement across 29 high- and low-income countries. American Journal of Sociology 88(6), 1162-1194.

Hox J. J. (1995). Applied multilevel analysis. Amsterdam: TT-Publicaties.

Hox, J. J. (1998). Multilevel modeling: When and why. In I. Balderjahn, R. Mathar, \& M. Schader (Eds.), Classification, data analysis, and data highways (pp. 147-154). Berlin: Springer.

Hox, J. (2010). Multilevel analyses: Techniques and applications (2nd Ed.). Mahwah, NJ: Erlbaum.

Johnson, M. K., Crosnoe, R., \& Elder, G. H. (2001). Students' attachment and academic engagement: The role of race and ethnicity. Sociol. Educ. 74(4), 318-340. Retrieved from http://dx.doi.org/10.2307/2673138

Kalaycioglu, D. B. (2015). The influence of socioeconomic status, self-efficacy, and anxiety on mathematics achievement in England, Greece, Hong Kong, the Netherlands, Turkey, and the USA. Educ Sci: Theory Pract., 15(5), 1-11. doi: 10.12738/estp.2015.5.2731

Kalender, I., \& Berberoglu, G. (2009). An assessment of factors related to science achievement of Turkish students. International Journal of Science Education, 31(10), 1379-1394. doi: 10.1080/09500690801992888

Kelley, K., \& Preacher, K. J. (2012). On effect size. Psychological Methods, 17, 137-152. doi: 10.1037/a0028086

Kreft, I. G. G. (1996). Are multilevel techniques necessary? An overview, including simulation studies (Unpublished manuscript). California State University, Los Angeles.

Krueger, A.B. (2003). Economic considerations and class size. The Economic Journal, 113(485), F34-F63. doi: 10.1111/1468-0297.00098

Leon, G., \& Valdivia, M. (2015). Inequality in school resources and academic achievement: Evidence from Peru. International Journal of Educational Development 40, 71-84. Retrieved from http://dx.doi.org/10.1016/j.ijedudev.2014.11.015

Ma, X., (2001). Stability of socioeconomic gaps in mathematics and science achievement among Canadian schools. Canadian Journal of Education 26 (1), 97-118. doi: 10.2307/1602147

Ma, X., \& Klinger, D. A. (2000). Hierarchical linear modeling of student and school effects on academic achievement. Canadian Journal of Education, 25(1), 41-55.

Maas, C. J. M., \& Hox, J. J. (2005). Sufficient sample sizes for multilevel modeling. Methodology, 1(3), 86-92. doi: 10.1027/1614-1881.1.3.86

McNeish, D. M., \& Stapleton, L. M. (2016). The effect of small sample size on two-level model estimates: A review and illustration. Educational Psychology Review, 28(2), 295-314. Retrieved from http://dx.doi.org/10.1007/s10648-014-9287-x

National Ministry of Education (MoNE), (2007). Report on student assessment program (SAP) 2005: Mathematics. Ankara: MoNE Directorate of Education and Instruction.

Organisation for Economic Co-operation and Development. (2011). Lessons from PISA for the United States, strong performers and successful reformers in education. Paris: OECD Publishing. 
Organisation for Economic Co-operation and Development. (2016). PISA 2015 Results: Excellence and Equity in Education (Vol. I). Paris: OECD.

Osborne, J. W. (2000). Advantages of hierarchical linear modeling. Practical Assessment, Research, and Evaluation, 7(1), 1-3.

Özberk, E. H., Atalay- Kabasakal, K., \& Boztunç-Öztürk, N. (2017). Investigating the factors affecting Turkish students' PISA 2012 mathematics achievement using hierarchical linear modeling. Hacettepe University Journal of Education, 32(3), 544-559. doi: 10.16986/HUJE.2017026950

Özdemir, C. (2016). Equity in the Turkish education system: A multilevel analysis of social background influences on the mathematics performance of 15-year-old students. European Educational Research Journal, 15(2), 193-217. doi: $10.1177 / 1474904115627159$

Parcel, T.L., \& Dufur, J.M., (2001). Capital at home and at school: effects on student achievement. Social Forces 79 (3), 881-911. doi: 10.1353/sof.2001.0021

Perry, L., \& McConney, A. (2010). Does the SES of the school matter? An examination of socioeconomic status and student achievement using PISA 2003. Teachers College Record, 112(4), 1137-1162.

Petrill, S. A., \& Wilkerson, B. (2000). Intelligence and achievement: A behavioral genetic perspective. Educational Psychology Review, 12(2), 185-199. Retrieved from https://doi.org/10.1023/A:1009023415516

Phan, H. T. (2008). Correlates of mathematics achievement in developed and developing countries: an hlm analysis of timss 2003 eighth-grade mathematics scores (Doctoral dissertation).University of South Florida.

Raudenbush, S. W., \& Bryk, A. S. (2002). Hierarchical linear models: Applications and data analysis methods, (2nd Ed.). Thousand Oaks, CA: Sage Publications.

Raudenbush, S., Bryk, A., Cheong, Y. F., Congdon, R., \& du Toit, M. (2011). HLM 7: Hierarchical Linear and Nonlinear Modeling [Computer Software]. Lincolnwood, IL: Scientific Software International, Inc.

Sirin, S. R. (2005). Socioeconomic status and academic achievement: A meta- analytic review of research. Review of Educational Research, 75(3), 417-453. doi: 10.3102/00346543075003417

Smits, J., \& Gündüz-Hoşgör, A. (2006). Effects of family background characteristics on educational participation in Turkey. International Journal of Educational Research, 26(5), 545-560. Retrieved from http://dx.doi.org/10.1016/j.ijedudev.2006.02.002

Snijders, T. A. B., \& Bosker, R. J. (2012). Multilevel analysis: an introduction to basic and advanced multilevel modeling (2nd Ed.). London: Sage.

Sweetland, S. R., \& Hoy, W. K. (2000). School characteristics and educational outcomes: toward an organizational model of student achievement in middle schools. Educational Administration Quarterly, 36(5), 703-729. doi: 10.1177/00131610021969173

Tabachnick, B. G., \& Fidell, L. S. (2014). Using multivariate statistics (6th Ed). New York, NY: Pearson Education

Tavşancıl, E., \& Yalçın, S. (2015). A determination of Turkish student's achievement using hierarchical linear models in trends in international mathematics-science study (TIMSS) 2011. Anthropologist, 22(2), 390396. doi: 10.1080/09720073.2015.11891891

The United Nations Children's Fund, (2016). Gender equality in secondary education. a literature review for UNICEF, NATCOM and Aydın Doğan Foundation.

Van Houtte, M. (2004). Why boys achieve less at school than girls: The difference between boys' and girls' academic culture. Educational Studies, 30(2), 159-173. doi: 10.1080/0305569032000159804

Veenstra, R., \& Kuyper, H. (2004). Effective students and families: The importance of individual characteristics for achievement in high school. Educational Research and Evaluation, 10(1), 41-70. doi: 10.1076/edre.10.1.41.26302

Willms, J.D., (1996). Indicators of mathematics achievement in Canadian elementary schools. In: HRDC (Eds.), Growing up in Canada: National longitudinal study of children and youth (pp. 69-82). Ottawa, Ontario: Human Resources Development Canada and Statistics.

Willms, D. J., Somers, M. A. (2001). Family, classroom, and school effects on children's educational outcomes in Latin America. School Effectiveness and School Improvement 12(4), 409-445.

Woltman, H., Feldstain, A., MacKay, J. C., \& Rocchi, M. (2012). An introduction to hierarchical linear modeling. Tutorials in Quantitative Methods for Psychology, 8(1), 52-69. doi: 10.20982/tqmp.08.1.p052

Wößmann, L. (2003). Schooling resources, educational institutions and student performance: The international evidence. Oxford Bulletin of Economics and Statistics, 65(2), 117-170. doi: 10.1111/1468-0084.00045

Yalçın, S., Demirtaşlı, R. N., İlgün-Dibek, M., \& Yavuz, H. Ç. (2017). The effect of teacher and student characteristics on TIMSS 2011 mathematics achievement of fourth-and eighth-grade students in Turkey. International Journal of Progressive Education, 13(3), 79-94. 
Yavuz, H. Ç., Demirtaşlı, R. N., Yalçın, S., \& İlgün-Dibek, M. (2017). The effects of student and teacher level variables on TIMSS 2007 and 2011 mathematics achievement of Turkish students. Education and Science, 42(189), 27-47. doi: 10.15390/EB.2017.6885

Yavuz, E., Tan, Ş., \& Atar, H., Y. (2019). Effects of students and school variables on SBS achievements and growth in mathematic. Journal of Measurement and Evaluation in Education and Psychology, 10(1), 96116. doi: 10.21031/epod.493297

\section{Türkiye'de Öğrenci ve Okul Özelliklerinin Ortaokul Öğrencilerinin Akademik Başarılarına Etkileri}

\section{Giriş}

Akademik başarı eğitim sisteminin niteliğine yönelik en önemli belirleyicilerden biridir. Birçok faktörün akademik başarıyı etkilediği görülmektedir (Börkan \& Bakış, 2016; Coleman ve diğerleri, 1966; EnginDemir, 2009; Gelbal, 2008). Araştırmalar sadece aile özelliklerinin değil aynı zamanda okul ve öğrenci özelliklerinin de öğrenci başarısını etkileyen önemli faktörler olduğunu göstermektedir (Alacacı \& Erbaş, 2010; Bellibaş, 2016; Börkan \& Bakış, 2016; Engin-Demir, 2009; Kalender \& Berberoglu, 2009; MEB, 2007).

Cinsiyet, yaş, motivasyon, derslere yönelik tutumlar, öz-yeterlik, öğrencilerin çabaları, okulda zorbalığa uğramak gibi birçok öğrenciye ait bireysel özellikler olup akademik başarı üzerinde anlamlı etkilere sahiptir (Engin-Demir, 2009; Ma, 2001; Özberk, Atalay-Kabasakal \& Boztunç-Öztürk, 2017; Yavuz, Demirtaş11, Yalçın, \& İlgün-Dibek, 2017). Ailenin sosyo ekonomik özellikleri, aile büyüklüğü ya da ailedeki kardeş sayısı, ebeveynlerin eğitim düzeyi öğrenci başarısında etkili olabilmektedir (Alacacı \& Erbaş, 2010; Börkan \& Balkış, 2016; Downey, 2001; Engin-Demir, 2009; Kalender \& Berberoglu, 2009; MEB, 2007). Okul ve öğretmen özellikleri de öğrenci başarısında etkili faktörlerdir (Atar, 2014; Bilican-Demir, 2018; Darling-Hammond, 2000; Phan, 2008; Tavşancıl \& Yalçın, 2015; Yavuz ve diğerleri, 2017). Öğrenci başarısı üzerinde sınıf büyüklüğü, okul büyüklüğü, okulun bulunduğu bölge, ortalama SES (Sosyo-Ekonomik Statü), öğretmen öğrenci oranı, öğretmen niteliği, eğitim kaynakları, çevre gibi faktörler okullar arasında farklılık oluşturabilmektedir (Leon \& Valdivia, 2015; Willms \& Somers, 2001).

Öğrenci başarısı değerlendirilirken birkaç yöntem kullanılmaktadır. Genel olarak final notları ya da not ortalamaları dikkate alınmaktadır. Standartlaştırılmış başarı testleri de öğrenci başarısı değerlendirilirken kullanılabilmektedir (Petrill \& Wilkerson, 2000). Uluslararası geniş ölçekli değerlendirme (örneğin; The Trends in International Mathematics and Science Study-TIMSS, Programme for International Student Assessment-PISA, and Progress in International Reading Literacy Study-PIRLS) ve ulusal geniş ölçekli değerlendirme ile öğrenci başarısı değerlendirilmektedir. Türkiye'de öğrenci başarısı üzerine birçok çalışmanın uluslararası TIMSS, PISA veya PIRLS veri setleri kullanılarak gerçekleştiği görülmektedir (Akyüz, 2014; Alacacı \& Erbaş, 2010; Anıl, 2009; Atar, 2014; Atar \& Atar, 2012; Dincer \& Uysal, 2010; Özdemir, 2016; Özberk ve diğerleri, 2017; Yalçın ve diğerleri, 2017). Ancak Türkiye'de akademik başarıya yönelik sadece birkaç çalışmada ulusal geniş ölçekli değerlendirmenin (örneğin; SBS, ÖBBS, TEOG) ya da başarı ortalamalarının kullanılarak gerçekleştiği görülmektedir (Börkan \& Bakış, 2016; Çiftçi, 2015; Engin-Demir, 2009; Gelbal, 2008; Yavuz, Tan \& Atar, 2019). Bu çalışma ortaokul öğrencilerinin akademik başarılarını etkileyen öğrenci ve okul özelliklerinin incelenmesini amaçlamaktır. Akademik başarı öğrencilerin genel not ortalamaları ile ölçülmüştür. Bu çalışmada dört araştırma sorusuna yanıt aranmıştır.

1. Okullar öğrencilerin ortalama akademik başarılarında ne kadar farklılık oluşturmaktadır?

2. Okullar öğrenci düzeyindeki değişkenler (örneğin, cinsiyet, SES, kardeş sayısı) ve akademik başarı arasındaki ilişkiye bağlı olarak ne kadar farklılık oluşturmaktadır? 
3. Okul düzeyinde değişkenler (okul büyüklüğü, öğrenci-öğretmen oranı, okul kaynakları) ortalama akademik başarının anlamlı yordayıcıları mıdır?

4. Okul düzeyinde değişkenler (okul büyüklüğü, öğrenci-öğretmen oranı, okul kaynakları) okullar arası ilişkide anlamlı yordayıcılar mıdır?

\section{Yöntem}

Bu çalışmada öğrenci düzeyinde ve okul düzeyinde değişkenlerin öğrenci başarısı üzerindeki etkilerini incelemek için hiyerarşik linear modelleme (HLM) yöntemi kullanılmıştır. İç içe gruplanmış yapıdaki veriler için HLM analizi kulllanılması Tip I hata yapmayı ve yanlı sonuçların önlenmesini sağlamaktadır (Gill, 2003; Osborne, 2000; Raudenbush \& Bryk, 2002). Çalışma grubunu, Ankara ve Sinop il merkezlerinde 10 ortaokula devam eden toplam 1053 yedinci sınıf ve sekizinci sınıf öğrencisi oluşturmuştur. Katılımcıların 512'sini (\% 48.6) kız öğrenciler, 541'ini (\% 51.4) ise erkek öğrenciler oluşturmuştur. Ortalama yaş 13.46 olup yaş aralığı 12 ile 15 arasında değişmektedir. Ortaokul ögrencilerine anket aracılı̆̆ ile çeşitli demografik sorular (cinsiyet, yaş, SES, kardeş sayısı) ve akademik başarı ortalamaları sorulmuştur. Veri analizi için HLM 7 kullanılmıştır. İki düzeyli HLM modeli kullanılarak öğrenci düzeyindeki ve okul düzeyindeki değişkenlerin akademik başarı üzerindeki etkileri incelenmiştir. Cinsiyet, SES ve kardeş sayısı öğrenci düzeyindeki değişkenleri oluştururken okul büyüklüğ̈̈, öğrenci-öğretmen oranı ve okul kaynakları okul düzeyindeki değişkenleri oluşturmuştur. Çalışmada öğrencilerin okullardaki dağılımı incelendiğinde, en yüksek öğrenci sayısının 235 ve en düşük öğrenci sayısının 68'dir. Çalışmada iki düzeyli model, HLM 7'nin hesapladığı sınırlandırılmış maximum olabilirlik ölçümü kullanılarak analiz edilmiştir (Raudenbush, Bryk, Cheong, Congdon \& du Toit, 2011).

\section{Sonuç ve Tartışma}

Bu çalışmada Türkiye'deki ortaokul öğrencilerinin akademik başarılarını etkileyen öğrenci ve okul özellikleri incelenmiştir. Araştırma bulguları, öğrenci özelliklerinin (cinsiyet, SES ve kardeş sayısı) ortaokul öğrencilerinin akademik başarıları üzerinde istatistiksel olarak anlamlı etkiye sahip olduğunu göstermiştir. Öğrenci değişkenlerinin akademik başarı üzerinde açıkladığı varyans oranı \%7'dir. Cinsiyetin öğrenci başarısı üzerinde güçlü bir etkiye sahip olduğu ortaya çıkmıştır. Diğer değişkenler kontrol edildiğinde, kız öğrenciler erkek öğrencilere göre daha yüksek başarı ortalamasına sahiptir. Bu araştırma sonucu diğer araştırma sonuçları ile benzerlik göstermektedir (Börkan \& Bakış, 2016; Güvendir, 2014; Engin-Demir, 2009; Van Houtte, 2004). Araştırmalar bazı sebeplerden dolayı kız öğrencilerin erkek öğrencilere göre daha iyi performans gösterdiklerini ortaya koymaktadır. Öğrencilerin tutumları, öz-yeterlikleri, okula bağlılıkları, akademik motivasyonları, derslerdeki çabaları kız ve erkek öğrencilerin akademik başarılarını farklı şekilde etkilemektedir (Batyra, 2017; EnginDemir, 2009; Gevrek \& Seiberlich, 2014; Van Houtte, 2004; Veenstra \& Kuyper, 2004). Ayrica, cinsiyet eşitliği okul başarısı için çok önemlidir. Türkiye'de 2000 yılından itibaren cinsiyet eşitliğini arttırmak adına önemli çalışmalar yapılmıştır. İlkokul ve ortaokulda özellikle kız öğrencilerin okullaşma oranları arttırılarak kız ve erkek öğrencilerin akademik başarıları arasındaki farklılık önemli ölçüde azalmıştır. $\mathrm{Bu}$ araştırma sonucunun da Türkiye'de okullarda cinsiyet eşitliğine yönelik yapılan projelerin olumlu etkilerini gösterdiği söylenebilir(The United Nations Children's Fund-UNICEF, 2016). Diğer taraftan kız öğrencilerin bazı alanlarda özellikle fen ve matematikte erkek öğrencilere göre daha düşük performans gösterme eğiliminde oldukları görülmektedir (Berberoğlu, 2004; Chiu \& Xihua, 2008; Farkas, Sheehan \& Grobe, 1990; Wößmann, 2003). Alan yazın genel olarak öğrencilerin akademik performanslarının cinsiyetlerine göre farklılık gösterdiğini ortaya koymaktadır. Bu nedenle, bu alana yönelik daha fazla çalışma yapılması oldukça önemlidir.

Etki büyüklüğü düşük olmasına rağmen, kardeş sayısı ve SES değişkenlerinin akademik başarı üzerinde anlamlı etkiye sahip olduğu ortaya çıkmıştır. Düşük SES'e sahip öğrencilerin daha düşük akademik ortalamaya sahip olma ihtimalinin daha yüksek olduğu bulunmuştur. Benzer şekilde, birçok araştırma düşük sosyo ekonomik statüye sahip aile ile yaşayan öğrencilerin okullarda düşük performans 
gösterdiklerini açığa çıkarmıştır (Alacacı \& Erbaş, 2010; Atar \& Atar, 2012; Aypay, Erdogan, \& Sozer, 2007; Bellibas, 2016; Dincer \& Uysal, 2010; Flores, 2007; Gelbal, 2008; Kalayc1oğlu, 2015; Perry \& McConney, 2010). Aynı zamanda bu araştırmada, kardeş sayısının akademik başarı üzerindeki negatif etkisi ortaya çıkmıştır. Özellikle gelişen ülkeler ve batı ülkelerinde, çok sayıda kardeş ve eğitim çıktıları arasında negatif yönde ilişki bulunmaktadır (Buchmann \& Hannum, 2001; Downey, 2001; Gelbal, 2008).

Araştırmada okul değişkenlerinin akademik başarı üzerindeki etkileri incelenmiştir. Öğrenci başarı ortalaması üzerinde yaklaşık \%11 oranında varyans, okullar arasındaki farklılıklar aracıllğı ile açıklanmaktadır. Okulun niteliği, okul büyüklüğü, öğretmen-öğrenci oranı ve okul kaynakları gibi değişkenler ile ölçülmüştür. Okul kaynaklarının (örneğin, kütüphane, bilgisayar laboratuvarı, fen laboratuvarı, müzik odası gibi) öğrenci başarısı üzerinde etkisi orta düzeydedir. Ancak okul büyüklüğü ve öğretmen-öğrenci oranının öğrenci başarısı üzerinde istatistiksel olarak anlamlı bir etkiye sahip olmadığı ortaya çıkmıştır. Alan yazın incelendiğinde okul kaynaklarının akademik başarı üzerindeki etkisine yönelik ortak bir görüş olmadığı görülmektedir. Bazı çalışmalar okul kaynaklarının akademik başarı üzerinde etkisinin olmadığını göstermektedir (Coleman ve diğerleri,1966; Hanushek, 1997; Hanushek \& Luque, 2003). Diğer taraftan bazı çalışmalar, okul kaynaklarının öğrenci çıktıları ile ilişkili olduğunu ortaya koymuştur (Card \& Krueger, 1996; Fuller \& Clarke, 1994; Özberk ve diğerleri, 2017). Daha iyi fiziksel ortama sahip bir okul, öğrenci başarısını pozitif yönde etkileyebilmektedir (Adeogun \& Osifila, 2008; Krueger, 2003; Parcel \& Dufur, 2001). Bu çalışmada da, bu araştırmaları destekleyen bulgulara ulaşılmıştır. 